\title{
Women in South Korean politics: a long road to equality
}

\section{Heike Hermanns, Australian National University}

Over the last 60 years, the Republic of Korea (hereafter South Korea or simply Korea) has undergone a dramatic transformation process. Within 40 years, the country developed from an agrarian society to one of the world's leading trading nations, in which economic development, modernisation and democratisation changed Korean society substantially. However, the position of women in Korean society changed at a slower pace, perpetuating gender inequality, particularly in politics and the economy. In terms of human development, Korea ranks among the industrialised countries (rank 28 on the United Nation's Human Development Index; HDI) but on the Gender Empowerment Measure (GEM) index, Korea holds a much lower position (68; UNDP 2004). ${ }^{1}$ The latter measures the position of women in politics and the economy and thus shows the low levels of women's participation at decision-making level in Korea.

This paper focuses on Korean politics and argues that democratisation has not yet delivered equal representation for women. Women make up only 13 per cent of National Assembly members, which is below regional and world average (IPU 2005). Without the pressure from female politicians, legislative changes in favour of gender equality are thus low on the agenda of parliament. Nonetheless, Korea has promulgated several advanced women's policies, including legislation outlawing domestic violence. The legislative changes are driven by an active women's movement under the

\footnotetext{
${ }^{1}$ The HDI is compiled using three indicators: longevity, knowledge, and a decent standard of living. For the full report and more information see http://hdr.undp.org/ [accessed 10/08/2005]. The GEM measures the degree of political and economic participation of women by looking at the percentage of seats held by women in parliament, women's GDP per capita, plus the percentage of female administrators and managers, and of female professional and technical workers.
} 
leadership of academics and feminists rather than female politicians. As part of their demands, measures of affirmative action for women including quotas have been introduced; leading to an increase in the number of women politicians in recent elections, but indications are that their advancement will be slow and gradual rather than by a sudden substantial expansion. Changes in women's policies will therefore continue to depend on pressure from outside representative institutions, showing the interdependence of political and civil society in Korea.

Since liberation in 1945, South Korea has developed almost beyond recognition. In the 1950s, Korea was an agricultural country slowly recovering from the destruction of the Korean War (1950-53). By the mid-1990s, Korea had become the $11^{\text {th }}$ largest trading nation in the world as a result of the ambitious industrialisation programme started in the 1960s. Per capita GDP increased from US\$100 in 1963 to over \$10,000 in 1995. With industrialisation, female labour force participation increased steadily to 49 per cent. Educational levels have risen dramatically, with 80 per cent of high school girls planning to enter college in the early 2000s. As Koreans flooded to the cities, urbanisation led to the decline of cohabiting multi-generational families in favour of nuclear family units. In spite of these dramatic changes, traditional values have continued to define the position of women in Korean society well into the 1990s.

The public-private dichotomy prescribed by Confucian teachings influenced attitudes towards a woman's role in family and public life (Lee 1996). A woman is expected to become a wife and mother, working within the realm of the household while a man represents the family to the outside world. Women are largely excluded from the political process by both the conservative elite and the electorate as the prevailing traditions look unfavourably on the political activity of women and question the ability of women in politics (Kim and Chin 1996, 127; Moon 2003). In line with these attitudes, women remain under-represented in higher positions in business and administration as well as in politics (Lee 2005, 136). ${ }^{2}$ Since the position of women in society is difficult to measure quantitatively, the presence of women in these areas gives some indication of gender equality and differences.

\footnotetext{
${ }^{2}$ At ministerial level women comprise 0.1 per cent of all positions. They make up 6 per cent of legislators, senior officials and managers, and 39 per cent of professional and technical workers (UNDP 2005).
} 
Since the early 2000s, the situation of women in Korea has undergone a transformation. Attitudes towards marriage and family are changing: Koreans are now older when they marry, have fewer children and are more likely to divorce. ${ }^{3}$ Women are also more likely to work and continue to stay in the workforce after marriage. With growing levels of education, women have been exposed to feminist ideas from abroad, leading to an active women's movement in Korea. Women's organisations have pushed for changes in attitudes and legislation that are slowly showing some effects. The gradual transformation of the position of women in Korean society is reflected in the increase of the Gender Empowerment Measure from rank 90 in 1995 to 68 in 2004 (Tables 1 and 2), although Korea remains at a lowly position surrounded by countries far less advanced economically.

Table 1: GEM and HDI, 1995

\begin{tabular}{lll}
\hline $\mathbf{1 9 9 5}$ & GEM & HDI \\
\hline Top ranking & Sweden & Canada \\
Australia & 11 & 2 \\
Malawi & 89 & 126 \\
South Korea & $\mathbf{9 0}$ & $\mathbf{3 0}$ \\
Tunisia & 91 & 80 \\
\hline
\end{tabular}

Source: UNDP (1995)

Table 2: GEM and HDI, 2004

\begin{tabular}{lll}
\hline $\mathbf{2 0 0 4}$ & GEM & HDI \\
\hline Top ranking & Norway & Norway \\
Australia & 8 & 3 \\
Georgia & 67 & 97 \\
South Korea & $\mathbf{6 8}$ & $\mathbf{2 8}$ \\
Cambodia & 69 & 120 \\
\hline
\end{tabular}

Source: UNDP (2004)

\footnotetext{
${ }^{3}$ The average number of years in school for women rose from 6.6 years in 1980 to 9.8 years in 2000. One-fifth of Korean women have attended college or university. The urbanisation rate climbed from 28 per cent in 1960 to 82 per cent in 2000. The average age of marriage rose from 21.6 years for women in 1960 to 27.5 years in 2004. Single-person households have more than tripled since 1975 to over 15 per cent in 2000. The birth rate fell from on average of six children in 1960 to 1.16 in 2004, one of the lowest rates in the world (data from Korean National Statistical Office, Korean Women's Development Institute, various years and databases).
} 
In response to pressure from women's organisations measures of affirmative action have been introduced, resulting in an increased success rate of women in elections since 2000. Women gained 9 per cent of seats in regional assemblies in the local elections of 2002 and 10.7 per cent in 2006. In 2004, female representation in the National Assembly more than doubled to 13 per cent (from 16 to 39 female lawmakers). Despite these increases, the majority of Korean women show little engagement in politics but serve only as an audience. The political process in South Korea thus continues to lack in descriptive representation and is inadequate in reflecting society and its various components. ${ }^{4}$ This in turn influences the political agenda, as a legislature’s composition impinges on its activities. In the literature on women's representation, strong links between the percentage of female legislators and women's policy outputs have been confirmed (Carroll 2001; Swers 2001, 173). Despite low levels of female legislative representation, however, South Korea has introduced progressive women's policies that are more advanced than in other countries with higher levels of female representation. This suggests that there is more than one way of influencing political procedures and policies in favour of women and the number of women in representative positions alone cannot be used to assess the progress of women's advancement. The relationship between descriptive and substantive representation needs to be investigated further.

This paper examines the causes and timing of the changes affecting women in Korea in more detail, in particular the different avenues for women to enter politics and to change women's policies. Political, socio-economic and cultural factors all play a role, including changes in political procedures, the accelerated speed of attitudinal change, in particular among young women, more outspoken women's organisations, and more progressive government policies. Events in Korea illustrate that women's policies can be promoted through other channels besides direct representation, showing the need to look beyond institutional representation for a fuller understanding of women's policymaking and measures to advance gender equality.

\section{Democratisation and procedural changes}

The Korean Sixth Republic (since 1988) is often cited as a successful model of democratisation (e.g. Diamond and Kim 2000). Since the mid-1980s Korea has undergone a successful transformation from military rule to representative democracy,

\footnotetext{
${ }^{4}$ See Pitkin (1967) for a discussion of representation.
} 
and free and competitive elections are held regularly at every level of government. Successive governments maintained and extended political rights and civil liberties. The consolidation of democracy in Korea is, however, not completed, as shortcomings remain with regard to democratic attitudes and behaviour, political parties and the dominance of regionalism in election outcomes (Shin 1999). Political parties are dominated by the personality of their leader, rather than programme or ideology. Due to the lack of distinguishing features among parties, regional voting became an important factor in Korean elections. Until the late 1990s, political parties had a conservative outlook, as progressive ideas were considered to be communistic and pro-North Korean. This has changed to some degree since 2000, when a generational change brought younger politicians into parliament (see Kihl 2005).

The democratisation process did not address the issue of gender inequality. ${ }^{5}$ In 1987 the conservative political elite was able to negotiate a peaceful transfer of power without the participation of more progressive forces, although the latter had initiated the transition process. The existing power structure and political culture dominated by conservative forces were transferred to the Sixth Republic. The number of female National Assembly members actually declined in the first three rounds of democratic elections (1988-1996; Table 3). From the Republic's foundation in 1948 until early 2004, only 72 women have been members of the National Assembly and only 25 of these have been elected directly. In this period the share of female representatives in the National Assembly averaged 2.5 per cent. In 2000, female representatives won 5.9 per cent only of the seats in the National Assembly, while the world average reached 13.9 per cent and the regional average 15 per cent (for single or lower houses). Even North Korea (DPRK) has a higher number of women in parliament (20.1 per cent; IPU 2005).

\footnotetext{
${ }^{5}$ Gender equality is largely overlooked in the democratisation process, by actors as well as by analysts.
} 
Table 3: Female representatives in the National Assembly:

\begin{tabular}{lrrrrr}
\hline & $\begin{array}{c}\text { Total } \\
\text { representative } \\
\text { Term }\end{array}$ & $\begin{array}{c}\text { Total } \\
\text { wome } \\
\text { n }\end{array}$ & $\begin{array}{c}\text { Women } \\
\text { \% }\end{array}$ & $\begin{array}{c}\text { Elected } \\
\text { women }\end{array}$ & $\begin{array}{c}\text { Prop. list/ } \\
\text { appointed }\end{array}$ \\
\hline $\mathbf{1 9 4 8 - 5 0}$ & 200 & 1 & 0.5 & 1 & - \\
$\mathbf{1 9 5 0 - 5 4}$ & 210 & 2 & 1.0 & 2 & - \\
$\mathbf{1 9 5 4 - 5 8}$ & 203 & 1 & 0.5 & 1 & - \\
$\mathbf{1 9 5 8 - 6 0}$ & 233 & 3 & 1.3 & 3 & - \\
$\mathbf{1 9 6 0 - 6 1}$ & 233 & 1 & 0.4 & 1 & 2 \\
$\mathbf{1 9 6 3 - 6 7}$ & 175 & 2 & 1.1 & 1 & 5 \\
$\mathbf{1 9 6 7 - 7 1}$ & 175 & 3 & 1.7 & 1 & 10 \\
$\mathbf{1 9 7 1 - 7 2}$ & 204 & 5 & 2.5 & 0 & 7 \\
$\mathbf{1 9 7 3 - 7 9}$ & 219 & 12 & 5.5 & 2 & 8 \\
$\mathbf{1 9 7 9 - 8 0}$ & 231 & 8 & 3.5 & 1 & 6 \\
$\mathbf{1 9 8 1 - 8 5}$ & 276 & 9 & 3.3 & 1 & 6 \\
$\mathbf{1 9 8 5 - 8 8}$ & 276 & 8 & 2.9 & 2 & 6 \\
$\mathbf{1 9 8 8 - 9 2}$ & 299 & 6 & 2.0 & 0 & 8 \\
$\mathbf{1 9 9 2 - 9 6}$ & 299 & 7 & 2.3 & 1 & 11 \\
$\mathbf{1 9 9 6 - 0 0}$ & 299 & 11 & 3.6 & 3 & 29 \\
$\mathbf{2 0 0 0 - 0 4}$ & 273 & 16 & 5.9 & 5 & 10 \\
$\mathbf{2 0 0 4 - 0 8}$ & 299 & 39 & 13.0 & 10 & - \\
\hline
\end{tabular}

Source: Korean National Election Commission, www.nec.go.kr, various sites, author's tabulation

Formal female representation is influenced by democratic procedures. During the democratic transition in Korea in 1987, the discussion regarding the electoral system was dominated by concerns about each party's chance of gaining the largest share of votes. The representation of minorities—including women—was given little consideration despite the appeals of Korean women's organisations, which had long demanded positive discrimination to address gender inequality in politics (Kim and Kim 1993, 233; Paek 1997). The constitution of the Sixth Republic stipulates single-member constituencies and includes a provision for proportional representation for about 20-25 per cent of the parliamentary seats, following the German model. The effects on female representation were not immediate, as Korean parties used the lists for other ends during the 1990s. Candidate rankings were influenced by a person's standing with the party leader and their profile in society. Nominees were generally expected to make a large donation to the party in return for a high ranking, so they were effectively buying a seat in the National Assembly and the prestige that came with it. Parties ran non-party members, such as women in leading positions in society and academia, to broaden the appeal of the party. Proportional lists have been an important avenue for women to enter the National Assembly and sub-national councils since very few women were successful in directly elected constituencies. 
Comparative studies of gender inequality in legislative representation conclude that the electoral system plays an important role in determining the number of seats held by female representatives (Norris 1987; Lovenduski and Norris 1993; Lijphart 1994). Women are found to make greater progress in electoral systems with multi-member districts and/or proportional lists (Darcy, Welch and Clark 1994). ${ }^{6}$ In single-member districts, parties aim at promoting a candidate acceptable to a majority of voters in order to win the seat. Putting a woman forward may jeopardise the party's success, so parties are reluctant to nominate female candidates (Matland and Studlar 1996: 709). In multimember districts, votes are more evenly spread between candidates, and second and third placed candidates are also successful, increasing female candidates’ chances of success. Moreover, voters are more likely to vote for a party rather than individual candidates, so that female candidates become more acceptable. However, multimember constituencies are not per se favourable for women: in a country where parties with several factions exist (as in Japan) multi-member seats can accommodate each faction, negating the (perceived) advantages for women.

In proportional systems, a set number of seats are allocated in accordance with the overall result of parties. Prior to the election each party creates a list of candidates, in order of importance, to take up these seats. This gives the central party administration greater influence on candidate selection and provides an opportunity to include women or other minorities in their list (if so inclined). A balanced list is more likely to appeal to a larger number of voters and can show the party’s commitment to equality as well as compensate for potential shortcomings in the selection of directly elected candidates. The outcome for women can be manipulated by strategic decisions, including quotas and favourable positioning. Since party lists are normally longer than the number of seats actually won, positioning women in the lower section of the list reduces their chances. Quotas are often introduced to ensure that a certain number of seats are allocated to women, but different applications affect the outcome and success of affirmative measures. In international comparison, quotas are most frequently used for seats allocated through party lists. The share reserved for women usually ranges from 20 per cent to 50 per cent, with a list that alternates between male and female candidates

\footnotetext{
${ }^{6}$ There are a number of possible variations: multi-member districts where each candidate seeks individual votes, multi-member districts with votes for party lists, and mixed systems of single-member constituencies and proportional lists.
} 
bringing the highest success rate for women. Quotas can be implemented either by law or by internal party rules and can be applied at different stages of the recruitment and selection process, i.e. during the process of short-listing candidates for selection within a constituency, in the selection process for electoral lists, or with a set number of parliamentary seats. The highest level of female representation can be expected in a system with a high quota for women in parliament, while a low quota for female applicants in the selection process would result in much less favourable results (Norris 2001). Countries around the world, in particular in Scandinavia, prove that quotas on proportional lists promote women's representation (Dahlerup and Freidenvall 2005, 27; Darcy, Welch and Clark 1994).

The usefulness of a quota system is contested on the grounds that there is a danger that women with insufficient qualifications may be chosen, who could stigmatise the reputation of female politicians per se and tarnish their image. Other critics see no gender differences and favour the selection of women on merit rather than on gender (Norris 2001; Ross 2002, 196). There is also a danger that quotas may be used as window-dressing when no action beyond implementing a quota is taken. Under these circumstances, female representation remains dependent on legislation and proportional lists without any attempt at removing barriers for women and creating a structure to support female politicians.

In Asia, Taiwan provides an example for the positive effect of quotas prescribed by legislation. The election law stipulates that at least one-fifth of the seats in local councils has to be filled by women. Should one party win more than four seats but fail to nominate a woman, the seat is automatically allocated to a female candidate from another party. Hence, parties are inclined to nominate women and consequently these women have a chance to gain political experience (Chou, Clark and Clark 1990, 194; Clark and Clark 1997, 15). As voters become used to female politicians, cultural objections to female representatives can decline. The number of female representatives in Taiwan has constantly been higher than the required percentage. In 2002, the percentage of women in city and county councils reached 22 per cent (with a higher percentage in the big cities). At the national level, women also gained 22 per cent of the seats in the Legislative Yuan in 2001. 
South Korea has experimented with several electoral systems since 1948. While for most of the Republic's existence the electoral system prescribed single-member districts, larger multi-member districts were in use during the Fifth Republic (19811988). This improved the chances of success for women: in the 1985 elections, and in fact two women were able to enter the National Assembly after achieving the secondbest result in their constituencies. However, when the electoral system reverted to single-member districts in 1988, these two representatives lost their seats, although they again gained the second highest vote in their district. A brief experiment with twomember districts for newly introduced regional elections was abandoned in the mid1990s. In 2005, the election law was changed again, re-introducing multi-member districts for city, county and district councils as well as proportional lists at this level of administration. This increased the share of women in local councils from 2.2 per cent to 15 per cent, with 75 per cent selected from proportional lists. ${ }^{7}$ A brief analysis shows that multi-member districts brought mixed results for women: the share of successful women in direct elections increased from 2.2 per cent to 4.3 per cent. However, the number of women winning their constituency actually declined by one-third (from 77 to 50; 2.2 per cent to 2 per cent of the total number of elected councillors), as more than half of the successful candidates (55 per cent) came second or third in their constituency. The reasons for this warrant further analysis.

Forms of proportional representation have been used in the National Assembly since 1963. In the 1960s and 1970s, candidate lists were compiled by the government, and often included persons with little political experience but high public profile. During the early 1980s, seats were allocated from party lists in accordance with the number of seats each party had won. Due to this system of preferential allocation, the number of female representatives increased but they had little effect on the promotion of women's issues and policies. These women were described as little more than 'ornaments on the political arena' (Sohn 1996, 116). The number of seats allocated proportionally was reduced in the Sixth Republic but they are still an important means for women to enter parliament. Female appointees have developed greater awareness as representatives for women but their small number limits their influence.

\footnotetext{
${ }^{7}$ There is the limitation that local elections are often decided on local issues, with no regard for gender equality. On the other hand, local politics are described as being more relevant to women and thus more likely to attract more female candidates (e.g. Elkin 1999).
} 
In the late 1990s, political parties began to show greater commitment to reducing gender inequality in order to project a modern image and to attract female voters. In the run-up to the presidential elections of 1997, the major parties introduced voluntary quotas for the allocation of seats on proportional lists, leading to the first occurrence of positive discrimination in the 1998 local elections. Two opposition parties vowed to allocate $30 \% 30$ per cent of the seats on their proportional list to women, while the ruling party promised a 50 per cent share. The commitment of local leaders to equal representation was an important factor in the implementation of quotas. Although Korean parties are generally highly centralised, local branches were given some leeway in this issue. Politicians at the local level were unsure about the exact percentage of the quota and it was not always enforced, particularly in more conservative rural areas (Hermanns 2000, 217).

After persistent pressuring and lobbying by women's groups and government members, the National Assembly promulgated changes to the Political Party Act that included an obligatory quota for women in 2000. Parties were required to allocate at least 30 per cent of the places on proportional lists to women, but there were no specific measures of enforcement or sanctions for non-compliance. The measure led to a moderate increase in female representation. In the $16^{\text {th }}$ National Assembly (2000-2004) the number of female lawmakers increased from 11 to 16, raising their share of seats from 2.3 per cent to 5.9 per cent. There were further changes prior to the 2002 local elections, which required that at least 50 per cent of the nominations for proportional seats and 30 per cent for direct candidacies had to be allocated to women. This latter regulation can be relatively easily circumvented by nominating women in areas where a party has little chance of winning anyway due to other factors such as regionalism. While more women entered parliament and councils on proportional lists, the success rate in directly contested constituencies increased very slowly. So far, there has been little evidence that the female representatives form a coalition across party allegiances to promote women's issues, as they tend to follow their respective party lines. Cooperation of representatives with women's organisations is also only developing slowly and on the basis of personal contacts (that are often already established). 


\section{The public sphere}

While quotas on proportional lists play an important role, they do not explain fully the increase in women parliamentarians in the early 2000s; other factors also play a role. As mentioned above, Korean society is currently going through a rapid transformation. ${ }^{8}$ Economic development, modernisation, democratisation and better education and welfare have weakened traditional values and led to some rapid changes in the attitudes of Korean women, but equality is far from being achieved (Kendall 2002, 6; Lee 2005). Despite their high levels of education, many women have difficulties in finding adequate employment, so staying at home after marriage is still a preferable lifestyle for many (Lett 1998; Kim 2002b, 211). ${ }^{9}$ However, a growing number of women continue to work after marriage, often out of economic necessity, but their progress into higher positions such as managerial posts is slow. Women are increasingly becoming more conscious about sharing economic, social and political rights and the male monopoly in the public sphere is no longer acceptable for many (Lee 2005). This is expected to have long-term effects on female representation, as women's advancement in the economy increases the pool of potential candidates for political office. Korean politicians often have a background in business, academia and the government administration but women are currently still under-represented in these professions. ${ }^{10}$ Results in Scandinavian countries show that only when women are widely accepted as equal players in all aspects of society as well as the economy are they successful in politics (Dahlerup and Freidenvall 2005, 31). ${ }^{11}$

Recent years have seen a change in Korean political actors. In the new millennium, the old guard of politicians who had developed their political tools under authoritarian regimes is retiring. Younger politicians and voters bring ideological and political change. In the second half of the 1990s, voters under the age of 40 became the largest voting block and more made inroads into political office. Born after the Korean War, they grew up without direct experience of poverty and deprivation and place more emphasis on democracy and human rights than on economic development at any cost

\footnotetext{
${ }^{8}$ The changes in Korean society are far too wide reaching to be covered here; for a more detailed analysis see for example Kihl (2005).

${ }^{9}$ More than half of the female workforce is employed in non-permanent positions, often in small family businesses.

${ }^{10}$ In 2005, 10 per cent of entrepreneurs are women, 15 per cent of university teachers and 7.4 per cent of bureaucrats at level 5 and higher.

${ }^{11}$ Interestingly, in Scandinavia, quotas were introduced voluntarily, and after women had already gained about 20 per cent of parliamentary seats.
} 
(Shin and Rose 2000, 34). Globalisation and the financial crisis of 1997 brought an end to the dominance of the conservative development model. As a result of these developments, Kim Dae-jung, a long-standing dissident, won the 1997 presidential elections. Kim favoured more progressive ideas and personally supported gender equality in various aspects of the public sphere. The government and women's organisations raised awareness of gender inequality and brought women's issues into the mainstream agenda.

\section{Cultural change}

Changes in attitude towards women among voters and political parties also played a role in the increase in women politicians. In the run-up to the 2004 elections, women projected an image as possible alternatives to the existing male-dominated politics, tarnished by corruption and power struggles. Incumbent female lawmakers had better performance records than their male colleagues, overcoming some of the prejudices about women's ability to perform successfully in politics. Women with parliamentary experience fared better than their male colleagues in elections: while two-thirds of the representatives in the $17^{\text {th }}$ National Assembly are newcomers, seven out of the ten female winners had previous parliamentary experience. By 2004, political parties had become more concerned with projecting a modern image that integrated women in their line-ups. This change resulted not only in a greater number of women in higher positions on proportional lists but also the selection of a woman as party spokesperson and thus the public face of the party. In the weeks leading up to the parliamentary elections in April 2004 all the three main parties designated a female speaker, while the main opposition party (the Grand National Party, GNP) also elected a woman, Park Geun-hye, as party president. ${ }^{12}$ These selections of female spokespersons were the first in which Korean parties did not wait for legislation to promote women but did so voluntarily.

\footnotetext{
${ }^{12}$ Park is the daughter of Park Chung-hee and profits from a feeling of nostalgia about his presidency (mostly among older and conservative Koreans). Park remained in office for more than two years. This is one of the few cases where a female politician could build on family connections. In contrast to other Asian countries such as Japan and the Philippines, few Korean women have (so far) 'inherited' a seat vacated by a family member. One exception is Hyun Kyung-ja who was elected to the National Assembly in 1994 after her husband lost his seat following a conviction for election law violations. She did not build a lasting career on this success.
} 


\section{Women's organisations}

With increasing levels of education more women have been exposed to ideas from abroad, including gender equality and feminism. The growing number of women's studies programmes at Korean universities (starting with Ewha Womans University in 1977) raised gender awareness in general and the number of women with genderspecific training in particular. Various women's studies departments in Korea and abroad have produced prominent feminist activists, bureaucrats and policy experts. One of the distinctive features of the Korean women's movement is the extensive involvement of feminist scholars in women's organisations and other civil groups as well as in the country's administration. Feminist academics at universities or research institutes have been involved in policy agenda setting and policy formation through participating in government committees and women's organisations, but few have become involved in legislative politics to date.

Since the late 1990s, female legislators have had little influence on the promotion of women's interests, the main actors being non-governmental organisations (NGOs) representing women's interests. Historically, women's organisations have been active in Korea throughout the $20^{\text {th }}$ century. During the Japanese colonial rule, nationalism and liberation rather than women's rights dominated the agenda. Women were granted suffrage in 1948 but remained largely excluded from politics by cultural conventions. Women's organisations were used by government and opposition for political purposes and mobilisation. The 'Korean National Council of Women', an umbrella organization founded in 1959 by middle-class women, for instance, was used as an agency to promote government policies, in particular family planning. Women workers were active in labour struggles throughout the 1970s and 1980s but women's issues were regarded as being of lesser importance compared to the problems of national division, military government and suppression of the working class. Under the authoritarian regimes of Park and Chun, women's organisations aimed at mobilizing women to the democracy movement and chose to collaborate with male-dominated groups rather than emphasize their autonomy and independence (Kim 2004, 471). Due to their roots in the opposition movement, there was a general reluctance among women's organisations to work with government agencies and to become involved in the political process. 
Following the successful struggle for democracy in the late 1980s, women's organisations began to focus on women's individual freedom, equality and human rights. Democratisation allowed women's organisations to become more professional and to diversify to reflect various strata, concerns and interests of women. Genderspecific issues, including equal opportunities and equal employment, rape and trafficking in women, and sex slavery during World War II, have come to dominate the agenda of women's organisations. Single-issue women's organisations play a critical role in advocating women and circulating new discourses on women's issues. The first rape crisis centre, for example, was established in 1991, bringing sexual violence onto the public agenda. However, many groups have a small number of active members and are dominated by one or a few leaders. Progressive women recognised the importance of cooperation for the advancement of women's issues and founded an umbrella organisation called 'Korean Women’s Association United', with 28 members nationwide in early 1987. More conservative groups were assembled under the umbrella of the aforementioned 'Korean National Council of Women' after it had gained greater independence from government influence. The two organisations cooperate to pursue their goals, unlike many other civic groups and political parties in Korea that are frequently plagued by factionalism and an inability to work together.

By the second half of the 1990s, most women's groups no longer saw the state as an antagonist, and concluded that engagement in legislative politics is a suitable means of gaining influence on politics and policies. Since the local elections of 1995, women's groups have actively supported female politicians with financial contributions, manpower (!) and education. Several women’s NGOs have set up campaign schools to identify potential talents and train women to be successful as politicians (with moderate success). But given the low number of female politicians in Korean politics, other avenues of influencing government policies are more significant. The Kim Dae-jung administration (1998-2003) emphasised the relationship of state and civil society and consequently, prominent NGO-leaders joined his administration, either as ministers, high-ranking officials or as advisors. In 1998, the 'Presidential Commission of Women's Affairs' was created, which reported directly to the president and had ministerial status in the cabinet. By 2001, it developed into the Ministry of Gender Equality with greater prestige and funding. The active participation of women's groups 
in the policy-making process was encouraged. As a result, women's organisations emerged as a new and influential social force.

The women's movement had produced a pool of well-qualified and trained activists who were willing to cross over into the political sphere, although not as elected representatives. Some activists have been invited on to government committees, which are one of the major mechanisms in the policy-making process. The appointment of two veteran leaders of women's groups to Kim's cabinet strengthened the ties with women's organisations. Academics, women's movement activists and legal experts were recruited for the 'Presidential Commission of Women's Affairs', ministries and also for the new women's offices in selected ministries. Other women activists act as advisors to a number of committees and ministries and also to the 'Special Committee for Women's Affairs' in the National Assembly, which serves as a channel to support the enactment and revision of the laws relating to women. In addition, feminist academics conduct government-commissioned research and thus promote women's policies. NGOs are permitted to submit proposals for legislations to the Committee and these are often accepted by both the Committee and the National Assembly with few changes. Korean legislative practices help: there is often only limited scrutiny and debate over proposed legislation, which is passed quickly to be amended later. In the case of the Family Violence Prevention Act, over 95 per cent of the original NGO-draft was accepted, although its outlook was far more progressive than that of the general populace (Jones 2004, 10). Proposals for legislations submitted by the Ministry of Gender Equality are also often influenced substantially by women's organisations (Yang 2002, 80).

The cooperation between feminists within government, feminist academics and women's organisations enabled the development and implementation of innovative and radical policies in Korea, including amendments to equal employment acts, the abolition of the family-register system and legislation outlawing sexual violence, prostitution and domestic violence (South Korea is the only country in East Asia with relevant legislation). Women's organisations influence government policies not only through well-qualified and trained activists but also undertake efforts to mobilise the general public for their causes, using diverse strategies such as lobbying, signature collections, demonstrations, and issue fighting. While women’s organisations are 
relatively well organised, groups that could present opposition are less coordinated. Conservative associations such as Confucian organisations have only a small active following that cannot muster substantial opposition. Political parties are also in a weak position to oppose legislative changes in favour of women. They depend on a broad basis of voters and thus aim at appealing to as many voters as possible, including women.

Despite the advances in women's policies there remain some concerns. The involvement of women in the policy making process alone does not lead to societal change. The new policies were implemented relatively quickly and without general societal consensus. The discrepancy between the laws and policies promulgated and the reality remains a problem as there is a significant gap between de jure and de facto gender equality. The public as well as government officials often lack information and understanding of new policies such as anti-harassment measures. The administration is habitually slow in implementing policies as bureaucrats are (sometimes) resisting change. This situation is reminiscent of the government's economic policies following the financial crisis of 1997. While the government promoted the economic opening up of the country, including foreign investment, many Koreans remained opposed to such policies (Jeon and Ahn 2000, 37). As a result, both investors and Koreans felt disadvantaged and little change occurred. To overcome these shortcomings the government and (women's) NGOs need to increase public education and information and lead by example.

The institutionalisation of the women's movement and its interdependence with the government has been criticised on several grounds, including concerns about the weakening of the movement's orientation, the diluted role as a critical edge and activities tailored by government-funded projects. Activists who joined the government were reprimanded for their decision to change sides and 'abandon' civil movements. There was even a joke that NGO stood for 'Next Government Official'. The departure of several leading figures left some women's groups with a much-weakened leadership. This is a precarious development as the presence of a strong, autonomous women's movement has been identified as a necessary condition for further progress in women's policy (Hassim 2003, 24). Not only the existence, but also the autonomy of women's groups is important for their success in influencing policy (Weldon 2002, 1161). Only 
an autonomous women's movement can criticise government policies and improve substantive representation in the policy-making process.

The autonomy of the women's movement with its many members is also undermined by funding issues. Many of the more progressive groups had been denied government funding previously but became eligible for support from the government in the late 1990s, although at a very low level. ${ }^{13}$ Major women's organisations, including 'Korean Women's Association United', became incorporated in order to secure their formal legitimacy and gain access to state funds. Other civil groups, however, have declined government support to maintain their independence (most prominently one of the biggest NGOs 'People’s Solidarity for Participatory Democracy'). Since there is only finite funding available, competition for government sponsorship erupted, leading to friction within the women's movement. Government support is also targeted at certain types of projects, steering activities in one direction, so that some groups have changed their focus in order to be able to access government funds (Kim 2004). Critics also point out that institutionalisation brought a less democratic decision-making process and increased the 'oligarchy' of a few organizations in the movement (Kim 2002a). Another point of criticism is that the concerns of the most disadvantaged women, such as working-class women, women in poor and rural areas, migrant women and sexual minority groups tend to be given less priority. This is partly explained by the background of activists and feminist academics who are mostly from a middle-class background and well educated (many have a post-graduate degree from overseas).

\section{Still a long road ahead}

Democratisation so far has failed to empower Korean women and lead to substantive representation. The political process continues to be dominated by a masculine public sphere that largely excludes women from the decision-making process. Gender discriminating attitudes among the political elites continue to function as important barriers to women's representation in politics. The pace of increase in female participation has been slow, indicating that in terms of descriptive representation in legislatures the process of democratic consolidation in Korea is still far from

\footnotetext{
${ }^{13}$ The main funding body, the Ministry of Gender Equality, received only 0.28 per cent of the total government budget in 2002.
} 
completed. ${ }^{14}$ It was only in the late 1990 s that the effects of modernisation reached Korean politics and political parties recognised the importance of female voters and of gender equality in representation. A combined effort by very active women's organisations and a progressive government was necessary to break down some of the barriers to female representation. Women's organisations play an important role in bringing women's issues onto the mainstream agenda and in promoting women's policies. Female politicians profit from this directly through government appointments and indirectly through the implementation of quotas that increase female legislative representation. While the cooperation between government and women's organisations has been successful so far, in the long term a cosy relationship between government and NGOs does not further democratic consolidation. In a representative democracy, elected legislators, rather than NGOs, should drive policy decisions.

The Korean example also demonstrates that the number of female representatives in legislatures alone is not a good measurement for the position of women in a society in general. Gender equality in politics and society is not reached in a linear process, simply requiring a larger number of women in parliament to promote women's policies. Substantive representation does not necessarily require descriptive representation or a large number of female representatives. Societal changes are induced by a number of interdependent factors. The GEM for Korea reveals this: despite the success of female representatives in 2004, Korea climbed only nine ranks to 59 in the 2005 report (UNDP 2005), as Korean women remain under-represented in professional and technical fields as well as in administrative positions. Further changes in attitudes about a woman's role in society are necessary to overcome this. Gender equality has to enter the public discourse as a major concern; one that is actively addressed by all societal groups.

The democratic process alone is not sufficient to engage and promote women politicians through active recruitment and strategic development. Women are far less politicised and thus less inclined to become politically active than Korean men (Shin 1999, 112). The government, political parties and NGOs have to make a concerted effort to increase women's representation. They need to provide the financial, educational and political support necessary to launch female political careers. Moreover,

\footnotetext{
${ }^{14}$ See also Shin (1999) and Kihl (2005) on the slow progress of Korean democratic consolidation.
} 
the public has to become more supportive of female politicians. Currently, most female politicians have a background in civil society movements but they provide a limited pool of candidates. Without new recruits there is the possibility that female representation will plateau at its current level without further sustainable growth. Quotas have been successful in bringing more women into the National Assembly, a trend that continued in local and regional elections in May 2006. However, the majority of women entered the Assembly via proportional lists, which highlights the difficulties to win in direct electoral contests. The results indicate that there still is a long road ahead before equality is achieved in Korean politics.

\section{Reference list}

Carroll, S.J. 2001, 'Representing Women: Women State Legislators as Agents of Policy-Related Change' in The Impact of Women in Public Office, S. J. Carroll (ed.), Indiana University Press, Bloomington, 3-21.

Chou, B., Clark, C. \& Clark, J. 1990, Women in Taiwanese Politics: Overcoming Barriers to Women's Participation in a Modernizing Society, Lynne Rienner, Boulder.

Clark, J. \& Clark, C. 1997; 'Women and Democratization in Taiwan: A Beginning More Than a Culmination', paper presented at the $19^{\text {th }}$ International Political Science Association Conference, Seoul.

Dahlerup, D. \& Freidenvall, L. 2005, 'Quotas as a 'Fast Track' to Equal Representation for Women', International Feminist Journal of Politics, vol. 7, no. 1, 26-48.

Darcy, R., Welch, S. \& Clark, J.1994, Women, Elections, and Representation, University of Nebraska Press, Lincoln.

Diamond, L.J. \& Kim, B. (eds) 2000, Consolidating Democracy in South Korea, Lynne Rienner, Boulder.

Elkin, S.L. 1999, 'Citizen Competition and the Design of Democratic Institutions', in Citizen Competence and Democratic Institutions, S.L. Elkin and K.E. Soltan (eds), Pennsylvania State University Press, University Park, 385-404.

Hassim, S. 2003, 'The Gender Pact and Democratic Consolidation: Institutionalizing Gender Equality in the South African State’, Feminist Studies, vol. 29, no. 3, 504528.

Hermanns, H. 2000, 'The State of Democratic Consolidation in Korea: Decentralisation and Participation in Local Politics, 1988-1998', PhD thesis, University of Newcastle-upon-Tyne.

International Parliamentary Union (IPU) 2005, Women in National Parliaments, World Classification [Online] Available: http://www.ipu.org/wmne/arc/classif151200.htm [Accessed 10/05/2005].

Jeon, B. \& Ahn, S. 2000, 'Korean Attitudes toward Foreign Firms', in The Two Koreas in 2000: Sustaining Recovery and Seeking Reconciliation, P. Köllner (ed.), Korea Economic Institute of America, Washington, 29-41.

Jones, N. 2004, 'Institutional Windows: Assessing the Scope for Civil Society-State Engagement in Democratizing South Korea', paper presented at the International Conference on Political Challenges and Democratic Institutions, Taipei, Department of Political Science, National Taiwan University. 
Kendall, L. 2002, 'Introduction' in Under Construction: The Gendering of Modernity, Class, and Consumption in the Republic of Korea, L. Kendall (ed.), University of Hawai'i Press, Honolulu, 1-24.

Kihl, Y. 2005, Transforming Korean Politics: Democracy, Reform, and Culture, M.E. Sharpe, Armonk.

Kim, S. 2002a, 'A Frame Analysis of Women's Policies of Korean Government and Women's Movements in the 1980s and 1990s', Korea Journal, vol. 42, no. 2, 536.

2002b, 'Gender Policy and the New Status of Women in South Korea' in Korea in Transition: Three Years under the Kim Dae-jung Government, C. Moon and D. I. Steinberg (eds.), Yonsei University Press, Seoul, 207-226. 2004, 'Consolidating Women's Rights in South Korea: The Role of Women's Movements in the Democratization', Korea Observer, vol. 35, no. 3, 463-483.

Kim, S. \& Kim M. 1993, 'Evaluation Report on Korean Women's Participation in Politics', Women's Studies Forum, vol. 9, 231-245.

Kim, Y. \& Chun K. 1996, 'A Study of the Political and Social Consciousness of Korean Women', Women's Studies Forum, vol. 2, 117-147.

Lee, M. 1996, 'Women's Education, Work, and Marriage in Korea: Women's Lives Under Institutional Conflict', $\mathrm{PhD}$ thesis, University of California.

Lee, K. 2005, 'Evolution of Women's Employment and Gender Discrimination in Korea', Korea Focus, vol.13, no. 5, 136-148.

Lett, D.P. 1998, In Pursuit of Status: The Making of South Korea's "New" Urban Middle Class, Harvard-Hallym Series in Korean Studies, Cambridge.

Lijphart, A. 1994, Electoral Systems and Party Systems: A Study of 27 Democracies, 1945-1990, Oxford University Press, New York.

Lovenduski, J. \& Norris, P. (eds) 1993, Gender and Party Politics, Sage, London.

Matland, R.E. \& Studlar, D.T. 1996, 'The Contagion of Women Candidates in SMD and PR Electoral Systems: Canada and Norway’, Journal of Politics, vol. 58, no. 3, 707-733.

Moon, S. 2003, 'Redrafting Democratization Through Women’s Representation and Participation in the Republic of Korea' in Korea's Democratization, ed. S. S. Kim, Cambridge University Press, Cambridge, 107-154.

Norris, P. 1987, Politics and Sexual Equality: The Comparative Position of Women in Western Democracies, Wheatsheaf, Brighton.

Norris, P. 2001, 'Breaking the Barriers: Positive Discrimination Policies for Women', in Has Liberalism Failed Women? Assuring Equal Representation in Europe and the United States, J. Klausen and C. S. Maier (eds), Palgrave, New York, 89-110.

Paek, Y. 1997, 'Politics of Implementing the Beijing Commitments in Selected Countries: The Korean Experience', paper presented at the $19^{\text {th }}$ International Political Science Association Conference, Seoul.

Pitkin, H. 1967, The Concept of Representation, University of California Press, Berkeley.

Ross, K. 2002, 'Women's Place in a 'Male' Space: Gender and Effect in Parliamentary Contexts', Parliamentary Affairs, vol. 55, no. 1, 189-201.

Shin, D. 1999, Mass Politics and Culture in Democratizing Korea, Cambridge University Press, Cambridge.

Shin, D. \& Rose, R. 2000, New Korea Barometer Survey 1999, Vol. 327, Studies in Public Policy, University of Strathclyde, Centre for the Study of Public Policy, Glasgow. 
Sohn, B. 1996, 'Uphill Battle for Women's Representation', Korea Focus, vol. 4, no. 3, 116-118.

Swers, M.L. 2001, 'Research on Women in Legislatures: What Have We Learned, Where are We Going?' Women and Politics, vol. 23, nos. 1-2, 167-185.

United Nations Development Programme (UNDP) 1995, Human Development Report 1995 [Online] Available:

http://hdr.undp.org/reports/global/1995/en/pdf/hdr_1995_ch1.pdf [Accessed 10/08/2005].

_2004, Human Development Report 2004 [Online] Available: http://hdr.undp.org/reports/global/2004/pdf/hdr04_complete.pdf [Accessed 10/08/2005].

2005, Human Development Report 2005; Gender Empowerment Measure [Online] Available:

http://hdr.undp.org/statistics/data/indicators.cfm?x=238\&y=2\&z=1 [Accessed $12 / 12 / 2005]$.

Weldon, S.L. 2002, 'Beyond Bodies: Institutional Sources of Representation for Women in Democratic Policymaking', Journal of Politics, vol. 64, no. 4, 1153-74. Yang, H. 2002, 'Unfinished Tasks for Korean Family Policy in the 1990s: Maternity Protection Policy and Abolition of the Family-Head System', Korea Journal, vol. 42, no. 2, 68-99. 